\title{
Alkali Catalysis of Different Vegetable Oils for Comparisons of Their Biodiesel Productivity
}

\author{
Ayten Sagiroglu, Hakki Mevlut Ozcan*, Sebnem Selen Isbilir, \\ Hatice Paluzar, Neslihan M. Toprakkiran \\ Department of Chemistry, Faculty of Science and Arts, Trakya University, Edirne, Turkey \\ Email: ${ }^{*}$ ozcanhakki@gmail.com
}

Received January 28, 2013; revised March 4, 2013; accepted March 14, 2013

\begin{abstract}
The main advantages of biodiesel are its biodegradability, renewablity, improved nontoxic exhaust emissions and unnecessary alteration of common diesel engines. Today, biodiesel is produced by catalysis of inorganic acids, alkali and free or immobilized lipases with vegetable oil and short chain alcohols. Alkali and acidic catalysts are the most using catalysts for production of biodiesel because of their higher reaction yield and rate. In this study, we have comprised biodiesel productivity of different vegetable oils like sunflower, safflower, canola, soybean, olive, hazelnut, corn oils and waste sunflower oils by alkali catalysis. The transesterification of oils were performed by using $\mathrm{NaOCH}_{3}$ as catalyst at $25^{\circ} \mathrm{C}$ and at $100^{\circ} \mathrm{C}$ for $1 \mathrm{~h}$. A defined amount of methanol as $6 / 1$ molar ratio to oil was pre-mixed with the metallic sodium. The amount of metallic sodium in methanol was $1.6 \mathrm{w} \%$ of oil mass for all of the crude oils/frying oil. Optimum reaction temperature was found as $25^{\circ} \mathrm{C}$. TLC (Thin Layer Choromatography) image and GC (Gas Choromatography) results demonstrates that the dominant fatty acid in safflower, soy bean, sunflower, canola, corn and waste sunflower oil esters was linoleic acid (18:2). Besides it was oleic acid (18:1) for the olive and hazelnut oil esters. When biodiesel productivities of eight different oils were compared, similar results were obtained.
\end{abstract}

Keywords: Biodiesel; Vegetable Oils; Alkali Catalysis; Transesterification; Sodium Methoxilate

\section{Introduction}

Exploring new energy resources has a great importance in recent years. Biodiesel has become more attractive recently because of its environmental benefits. With recent increases in petroleum prices and uncertainties concerning petroleum availability, there is renewed interest in vegetable oil fuels for diesel engines. In Europe, the most important biofuel is biodiesel. In the European Union biodiesel is by far the best biofuel and represents $82 \%$ of the biofuel production for 2003 [1].

Biodiesel production commonly involves the transesterification of a triglyceride feedstock with methanol or other short-chained alcohols [2,3]. The term biodiesel refers to the alkali esters of fatty acids produced during this chemical reaction, with glycerin being the primary by product. Biodiesel can be used alone, or more commonly it is blended with petroleum based diesel. Biodiesel has a number of important benefits which include: the fuel is renewable, the fuel burns cleaner in most major emission categories, biodiesel is compatible with current fuel infrastructure, the addition of biodiesel improves lubricity of diesel blends, the use of biodiesel

${ }^{*}$ Corresponding author. reduces petroleum dependence while potentially promoting domestic jobs [4]. The primary concern of biodiesel producers has been a stable supply of low-cost oil feedstock that yields a quality biodiesel product competitive in price with petroleum diesel fuels. Refined oils produced from large-scale seed oil crushing operations currently commands a high value within the edible market due to its excellent functionality as cooking oil.

Biodiesel production reactions were carried out with inorganic homogeneous catalysts such as acidic $(\mathrm{HCl}$ or $\mathrm{H}_{2} \mathrm{SO}_{4}$ ), alkali ( $\mathrm{NaOH}, \mathrm{KOH}$ or $\mathrm{KOCH}_{3}, \mathrm{NaOCH}_{3}$ ) and inorganic heterogeneous catalysts as metal oxides $(\mathrm{MgO}$, $\mathrm{CaO}, \mathrm{Al}_{2} \mathrm{O}_{3}$ or $\mathrm{Al}_{2} \mathrm{ZnO}_{4}$ ). Methanol and ethanol, being cheaper, is the most common used during transesterification reaction $[5,6]$. Non catalyst transesterification processes are the BIOX process and the supercritical alcohol (methanol) process.

Last years, lipases, which have oils as natural substrates that can be used as a biocatalyst, such as free or immobilized form in biodiesel production processes, are investigated widely. Lipases were immobilized on different inert supports for reasons such as being reusable, protective of enzyme activity, stability and simply removable from reaction medium [7-9]. Therefore using of 
immobilized lipases in oils transesterification has more advantages than free enzymes. Biodiesel synthesis with immobilized enzyme catalyst were carried out under moderate conditions and obtained the most pure biodiesel products while minimizing other by-products. In addition, the biodiesel is composed of fatty acid methyl-ethyl esters and monoglycerides blended in a molar ratio of $2 / 1$. It resembles the physico-chemical properties of conventional biodiesel and/or petro diesel, avoiding the production of glycerin as by product. Although the enzymecatalyzed biodiesel production processes are not yet commercially developed, new results have been reported in recent articles and patents [10].

A series of improvements in conversion levels and/or the use of methanol as alcohol to mimic the results of the base catalyzed transesterification reaction are currently ongoing as a consequence of the present legal regulations for biodiesel (European biodiesel standard EN 14214). Reasonably good results are sometimes reported due to the 1,2-acyl migration in the monoglycerides [11,12].

The current standard biodiesel production under alkaline conditions is considered to be the most technically simple way to reduce the viscosity of vegetable oils from a range of $11-17$ times $[13,14]$ to just about twice to that of petroleum diesel.

This research is related to earlier studies in which refined, crude and waste oils from eight different oils were evaluated for variation in some physical properties such as viscosity, density and propensity of the oils to biodiesel productivity. Significant variation was noted among these parameters with differences generally being well explained by the differing fatty acid profiles of these oils. As such, the current research allows for a unique opportunity to directly compare of oil feedstock species of vegetable oils such as sunflower, safflower, canola, soy, olive oils and waste sunflower oils with the consequence biodiesel productivity of by alkali catalysis.

\section{Experimental}

\subsection{Materials}

The crude food oils such as sunflower, corn and canola oils were obtained from Olin Oil Factory in Edirne-Turkey. Unrefined safflower oil was obtained from safflower producers of Nigde-Turkey, unrefined soybean oil was obtained from Adana-Turkey, crude olive oil was obtained from Aydın-Turkey, crude hazelnut oil was obtained from Ordu-Turkey and roasted-waste sunflower oils was obtained from Trakya University restaurant in Edirne-Turkey.

TLC (Thin Layer Choromatography) plate, metallic $\mathrm{Na}$, iodine, methanol, n-heptane, petroleum ether, diethyl ether, acetic acid for TLC solvent system, oleic and linoleic acid methyl esters, pure oleic and linoleic acids as standards and other chemicals were purchased from Merck and Sigma-Aldrich.

\subsection{Determination of FFA Compositions in the Crude Oils and Biodiesel}

The fatty acids containing of vegetable oils were analyzed using a model 6890N Agilent-GC (Gas Chromatography) with a DB-23 capillary column and a flame ionization detector. Five micro liters of the sample and 300 $\mu 1$ of $1.4 \mathrm{mM} / \mathrm{L}$ heptadecanoic acid methyl ester (hexane as the solvent) which is served as the internal standard were precisely measured and mixed thoroughly. The column temperature was kept at $180^{\circ} \mathrm{C}$ for $0.5 \mathrm{~min}$, heated to $250^{\circ} \mathrm{C}$ at $15^{\circ} \mathrm{C} / \mathrm{min}$, and then maintained for $6 \mathrm{~min}$. The temperatures of the injector and FID detector were set at $245^{\circ} \mathrm{C}$ and $250^{\circ} \mathrm{C}$, respectively.

\subsection{Properties of the Used Oils}

Oil Density: The oil densities were determined by using the standard method ASTM D7042.

Oil pH: 2 g. of the sample was poured into a clean dry $25 \mathrm{ml}$ beaker and $25 \mathrm{ml}$ of hot distilled water was added to in the beaker and stirred slowly. Then it was cooled to $25^{\circ} \mathrm{C}$ in a water bath. The $\mathrm{pH}$ electrode was standardized with buffer solution and the electrode immersed into the sample and the $\mathrm{pH}$ value was measured.

Oil Viscosity: The oils viscosities were determined by using an A\&D's vibro viscometer. SV series Sine-Wave Vibro Viscometer is designed for sensitive measurement of viscosity providing a wide dynamic range and high resolution by vibrating with a frequency of about $30 \mathrm{~Hz}$ equivalent to the resonance of the detection system. Vibro viscometer measures the driving electric current to vibrate the sensor plates with a uniform frequency and amplitude, and than the viscosity is given by the positive correlation between the driving electric current and the viscosity. The viscosity coefficient is given by the correlation between the driving electric current and the magnitude of viscidity (viscosity coefficient: I). The correlation between electromagnetic drive unit and driving electric current can be obtained from the equation: $\log \eta=\mathrm{a}$ $\log \mathrm{I}^{2}+\mathrm{b} \log \mathrm{I}+\mathrm{C}$, where viscosity $\eta$, driving electric current $\mathrm{I}$ and $\mathrm{C}$ is the constant calibration of measuring system which is given by the manufacturer at the $40^{\circ} \mathrm{C}$. The kinematics viscosity $(v)$ also represents the ratio between the dynamic viscosity $(\eta)$ and density $(\rho),(v=$ $\eta / \rho)$.

\subsection{Preparation of Oils for Biodiesel Production}

The oils were filtered to remove any of the debris present. The oils were evaporated for 20 minutes at $100^{\circ} \mathrm{C}$ to separate the water. The amount of water in oils was re- 
duced approximately as $<0.01(\mathrm{w} \%)$. Therefore, the fulfillment of the required standard limit for water content was provided. Water amount of the oil is very important because excess amount of water in oil is disadvantaged for biodiesel production. At the end, the temperature of oils was brought down to desired degree.

\subsection{Preparation of Basic Catalyst}

The methanol was dried by activated silica granule and cooled in deepfreeze. Metallic sodium was taken from stock in hexane; its surface was cleaned with steel knife and weighed quickly. $\mathrm{NaOCH}_{3}$ catalyst was prepared by dissolving a little part of cleaned-weighed metallic sodium into $50 \mathrm{ml}$ of cool-dry methanol until desired concentration.

\subsection{Biodiesel Production}

In our preliminary tests, type and concentration of catalyst, methanol/oil ratio, reaction period for biodiesel production were determined using sunflower crude oil and the founded optimal values were used during subsequent following experiments [7].

There are two major steps at the biodiesel production: synthesis and purification. Transesterification experiments for biodiesel synthesis were carried out under atmospheric pressure using $\mathrm{NaOCH}_{3}$ as catalyst. The reaction was performed in a $100 \mathrm{~mL}$ reaction flask with the connection of reflux condenser. The reaction flask was placed on a heater with magnetic stirrer. The catalyst and crude oils prepared as above were mixed and put into the reaction flask. The heater was settled with an error of \pm $2{ }^{\circ} \mathrm{C}$ and the magnetic stirrer rate adjusted as $200 \mathrm{rpm}$ (stirrer rate was determined preparatory works). A defined amount of methanol (6:1 molar ratio to oil) was prepared with metallic sodium before the main reaction as described above. The amounts of catalyst was $1.6 \mathrm{w} \%$ of oil for all of crude oils/frying oil. At this point, the reaction was started. The temperature of mixture was gradually raised from 10 up to $100^{\circ} \mathrm{C}$ during 1 hour. After the reaction time was over, the mixture was transferred to a separatory funnel and it was put aside for a day to separate ester phase and glycerin phase. Furthermore, the transesterification reaction was carried out again by using all of the oils at $25^{\circ} \mathrm{C}$ for $1 \mathrm{~h}$.

In purification step of biodiesel, Excess methanol, catalyst and glycerin were removed from methyl esters by washing with distilled water. The ester phase was placed in the separation funnel. Water was sprayed onto the top of the funnel at a low speed. For complete settling of water, $24 \mathrm{~h}$ were required. At the and of this period the biodiesel produced during the reaction was dried over anhydrous sodium sulphate for a night and finally filtered under reduced pressure to obtain the final biodiesel and biodiesel was weighed.

After the biodiesel production, conversion ratios of oils to biodiesel were calculated on the basis of the ratio of obtained biodiesel amounts to used crude oils amounts (w/w) and described as biodiesel productivities (\%).

\subsection{TLC and GC Analysis of Biodiesel}

TLC qualitative analysis of fatty acid methyl esters (FAME, biodiesel products) were carried out on silica gel plate with TLC. Petroleum ether: diethyl ether: acetic acid (8:3:0.2) solvent system was used as mobile phase at the presence of standards (Oleic acid, Linoleic acid methyl esters (biodiesel), Carotene). After $1 / 2$ hour, the TLC plate was dried at the $110^{\circ} \mathrm{C}$ and then colored in iodine chamber for all of the over varieties.

For the quantitative analysis, the vegetable oils feedstocks and the FAME in the biodiesel were diluted into n-heptan and GC analyses were performed with model 6890 Agillent GC as "Determination of FFA compositions in the crude oils and biodiesel" section.

\section{Results and Discussion}

\subsection{GC Analysis of Oils and Other Properties}

GC Analysis results of free fatty acid compositions for used vegetable oils were given in Table 1 . The fatty acid contents of oils was generally unsaturated (18:1 and 18:2) fatty acids rich according to GC analysis. The fatty acids which were commonly found in vegetable oils were palmitic (16:0), stearic (18:0), oleic (18:1), linoleic (18:2) and linolenic (18:3). According to the results it was observed that the safflower, waste sunflower, sunflower, corn and soybean oils contained higher percentages (72.3, $59.6,58.5,58.4$ and $56.2 \%$, respectively) of linoleic acid when copmpared to the others, the hazelnut, olive and canola oils contained higher percentages (78.0, 74.7 and $63.0 \%$, respectively) of oleic acid.

Some physical properties of vegetable oils were measured before the biodiesel production. The oil density, $\mathrm{pH}$ and dynamic viscosities of oils were shown in Table 2.

\subsection{Conversion Ratios of Oils to Biodiesel}

The effects of alkali catalyst $\left(\mathrm{NaOCH}_{3}\right)$, temperature and feedstock oil type on productivity of biodiesel production were investigated. The parameters affecting on the biodiesel productivity are catalyst type-concentration, reaction temperature, molar ratios of catalyst-methanol-oil, water content, and FFA content.

The results of biodiesel productivity of different vegetable oils by $\mathrm{NaOCH}_{3}$ catalyst at the $25^{\circ} \mathrm{C}$ and $100^{\circ} \mathrm{C}$ were given Table 3 . Considering the obtained results, it was clear that the studied homogeneous $\mathrm{NaOCH}_{3}$ catalyst were effective to obtain a pure biodiesel according to the 
Table 1. GC Analysis of fatty acids in the oils.

\begin{tabular}{ccccccccccccc}
\hline \multirow{2}{*}{ Oil samples } & \multicolumn{1}{c}{ Fatty acid compositions (\%) } \\
\cline { 2 - 11 } & $14: 0$ & $16: 0$ & $16: 1$ & $18: 0$ & $18: 1$ & $18: 2$ & $18: 3$ & $20: 0$ & $24: 0$ & Others \\
\hline Safflower & 0.30 & 7.3 & 0 & 1.9 & 13.6 & 77.2 & 0 & 0.3 & 0 & 0 \\
Soy bean & 0 & 13.9 & 0.3 & 2.1 & 23.2 & 56.2 & 4.3 & 0.16 & 0 & 0 \\
Sunflower & 0.08 & 6.1 & 0.12 & 3.71 & 30.0 & 58.5 & 0.11 & 0.23 & 0.15 & $0.58(20: 5)$ \\
Canola & 0 & 4.72 & 0.19 & 1.80 & 63.0 & 19.8 & 7.88 & 0 & 0 & $0.26(20: 5)$ \\
Corn & 0.26 & 10.8 & 0.08 & 2.23 & 26.1 & 58.4 & 0.91 & 0.43 & 0 & 0. \\
Olive & 0,40 & 5.0 & 0.32 & 1.68 & 74.7 & 17.6 & 0 & 0.80 & 0 & 0 \\
Hazelnut & 0.1 & 5.2 & 0.3 & 2.1 & 78.0 & 13.8 & 0.3 & 0.1 & 0 & $0.2(22: 0)$ \\
Frying sunflower & 0 & 5.8 & 0.10 & 3.82 & 30.6 & 59.6 & 0.10 & 0.20 & 0.14 & 0 \\
\hline
\end{tabular}

Table 2. Density, pH and dynamic viscosities of oils.

\begin{tabular}{ccccc}
\hline \multirow{2}{*}{ Oil samples } & $\mathrm{pH}$ & Density $(\rho),(\mathrm{g} / \mathrm{ml})$ & \multicolumn{2}{c}{ Dynamic Viscosity $(\eta)\left(\mathrm{mPa}{ }^{*} \mathrm{~s}\right)$} \\
\cline { 2 - 5 } & $25.5^{\circ} \mathrm{C}$ & $25.5^{\circ} \mathrm{C}$ & $25.5^{\circ} \mathrm{C}$ & $40^{\circ} \mathrm{C}$ \\
\hline Safflower & 6.78 & 0.922 & 39.7 & 23.4 \\
Soy bean & 6.88 & 0.920 & 41.4 & 23.6 \\
Sunflower & 6.02 & 0.918 & 41.4 & 23.1 \\
Canola & 5.85 & 0.929 & 44.7 & 25.3 \\
Corn & 6.63 & 0.916 & 44.7 & 24.8 \\
Olive & 6.96 & 0.909 & 43.6 & 25.6 \\
Hazelnut & 6.75 & 0.919 & 50.4 & 26.7 \\
Frying sunflower & 5.36 & 0.915 & 44.9 & 24.6 \\
\hline
\end{tabular}

Table 3. Biodiesel productivity of different vegetable oils by alkali catalysis.

\begin{tabular}{|c|c|c|c|}
\hline \multirow{2}{*}{ Oil samples } & \multicolumn{2}{|c|}{ Biodiesel productivity (\%) } & \multirow{2}{*}{$\begin{array}{c}\text { Productivity increase depend on } \\
\text { temperature (\%) }\end{array}$} \\
\hline & $25^{\circ} \mathrm{C}$ & $100^{\circ} \mathrm{C}$ & \\
\hline Safflower & 63.4 & 74.9 & 7.6 \\
\hline Soy bean & 66.4 & 68.1 & 2.6 \\
\hline Sunflower & 64.5 & 69.5 & 7.8 \\
\hline Canola & 61.6 & 64.2 & 4.2 \\
\hline Corn & 68.0 & 72.2 & 6.2 \\
\hline Olive & 61.4 & 65.1 & 6.0 \\
\hline Hazelnut & 67.0 & 77.7 & 7.2 \\
\hline Frying sunflower & 63.8 & 64.6 & 0.5 \\
\hline
\end{tabular}

European biodiesel standard EN 14214 for all of the used crude oils/frying oil. Apparently, the important effect of types of crude oils/frying oil were not found on biodiesel productivity.

When the effects of temperature on biodiesel produc- tivity investigated, the highest productivity was found when used corn oil $(68 \%)$ and also the lowest productivity was found when used canola oil $(61.6 \%)$ at the $25^{\circ} \mathrm{C}$. However, at the $100^{\circ} \mathrm{C}$ the biodiesel productivities of varieties of crude oils generality were found higher than 
productivity results at the $25^{\circ} \mathrm{C}$. The highest productivity was found when used hazelnut oil (77.7\%) and also the lowest productivity was found when used canola oil $(64.2 \%)$ at the $100^{\circ} \mathrm{C}$.

As seen in the Table 3, the increases on biodiesel productivity depending on temperature were between $1.3 \%$ and $18.1 \%$ for all of the crude oils/frying oil from $25^{\circ} \mathrm{C}$ up to $100^{\circ} \mathrm{C}$. In the study, obtained biodiesel productivities were average between $61 \%-68 \%\left(25^{\circ} \mathrm{C}\right)$ and $64 \%$ $78 \%\left(100^{\circ} \mathrm{C}\right)$ by using $\mathrm{NaOCH}_{3}$ as catalyst. Finally, that was seen from results, increase of temperature as well as $100^{\circ} \mathrm{C}$ didn't significantly increase biodiesel productivity $(\sim 10 \%)$. Moreover, although a reflux condenser was used in the experiment to avoid methanol losses, the methanol will vaporize when the reaction temperature exceeds the boiling point of methanol. In addition, in order to avoid oxidation reactions on multi unsaturated fatty acids it is not necessary to increase reaction temperature until $100^{\circ} \mathrm{C}$ and biodiesel production at $25^{\circ} \mathrm{C}$ can be preferred and also it has advantages economically. Similar results have also been found in related studies [15-17].
TLC and GC analyses of obtained biodiesel products were performed as described above. The results were given in Figure 1. As it can be seen from TLC images, the abundant parts of crude oils/frying oil transformed to biodiesel form.

GC results of FFA's esters of produced biodiesels were shown in Table 4. As expected, similar fatty acid compositions were observed in the biodiesels produced from the different feed stocks. The dominant fatty acid in safflower, soy bean, sunflower, canola, corn and waste sunflower oil esters was linoleic acid (18:2), averaging at $82 \%, 64 \%, 58 \%, 57 \%, 60 \%$ and $55 \%$, respectively. In the olive and hazelnut oil esters, it was oleic acid averaging at $53 \%$ and $57 \%$, respectively. All of the oil esters had very highly unsaturated fatty acid content, ranging from about $80 \%$ - 92\%. Also some saturated fatty acids as palmitic (16:0) and steraic (18:0) were found minor amounts in these esters. TLC image and GC results demonstrates that biodiesel productivities were not found important differences among all of the oil types by alkali catalysts.

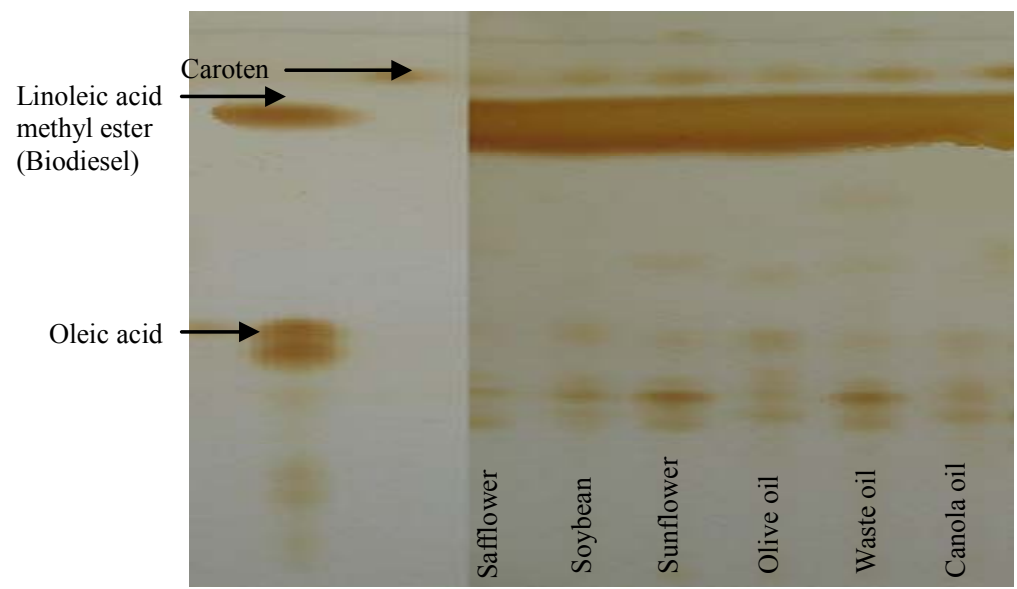

Figure 1. TLC image of produced biodiesels from crude oils/frying oil and standards \{Oleic acid, linoleic acid methyl esters (biodiesel), carotene\} by alkali catalysis.

Table 4. GC results of FAME in produced biodiesels by alkali catalyst.

\begin{tabular}{|c|c|c|c|c|c|c|c|c|c|c|}
\hline \multirow{2}{*}{ Oil samples } & \multicolumn{10}{|c|}{ FAME compositions of biodiesels $(\%)$} \\
\hline & $14: 0$ & $16: 0$ & $16: 1$ & $18: 0$ & $18: 1$ & $18: 2$ & $18: 3$ & $20: 0$ & $24: 0$ & Others \\
\hline Safflower & 0.21 & 7.76 & 0.27 & 0 & 7.86 & 82.34 & 0.21 & 0.06 & 0.05 & $0.33(22: 0)$ \\
\hline Soy bean & 0.12 & 13.00 & 0 & 0 & 13.13 & 64.38 & 7.66 & 0.05 & 0 & $0.37(22: 0)$ \\
\hline Sunflower & 0.09 & 5.80 & 0.22 & 0 & 34.09 & 57.94 & 0.12 & 0.22 & 0.16 & $0.69(22: 0)$ \\
\hline Canola & 0.34 & 13.11 & 1.02 & 0 & 0 & 56.60 & 22.27 & 0.09 & 0 & $0.14(22: 0)$ \\
\hline Corn & 0.11 & 11.81 & 0.30 & 0 & 25.47 & 59.63 & 1.08 & 0.46 & 0.03 & $0.10(22: 0)$ \\
\hline Olive & 0.11 & 8.08 & 0.65 & 0 & 53.36 & 25.65 & 9.41 & 0.18 & 0 & $0.48(22: 0)$ \\
\hline Hazelnut & 0.07 & 4.81 & 0.26 & 0 & 57.33 & 19.98 & 1.54 & 0.10 & 0.04 & 0 \\
\hline Waste sunflower & 0.38 & 15.04 & 0.48 & 3.87 & 28.44 & 54.75 & 0.17 & 0.27 & 0.18 & $0.27(22: 0)$ \\
\hline
\end{tabular}




\section{Conclusions}

Today and future, methyl and ethyl esters of vegetable oils have several outstanding advantages among other new renewable and clean engine fuel alternatives. Considering the present work and from the perspective of optimizing biodiesel production using the different feed stocks and $\mathrm{NaOCH}_{3}$ catalysts, the following conclusions might be considered:

In this study, obtained biodiesel productivities were average between $61 \%-68 \%\left(25^{\circ} \mathrm{C}\right)$ and $64 \%-78 \%$ $\left(100^{\circ} \mathrm{C}\right)$ by $\mathrm{NaOCH}_{3}$ catalysts. Increase of temperature increased biodiesel productivity approximately $10 \%$. This is not effective enough and economically it is not necessary to increase temperature until $100^{\circ} \mathrm{C}$ so that reaction temperature was preferred as $25^{\circ} \mathrm{C}$.

TLC image and GC results demonstrates that the dominant fatty acid in safflower, soy bean, sunflower, canola, corn and waste sunflower oil esters was linoleic acid $(18: 2)$. In the olive and hazelnut oil esters, it was oleic acid (18:1). All the oil esters had very highly unsaturated fatty acid content, ranging from about $80 \%-92 \%$. Also some saturated fatty acids as palmitic (16:0) and steraic (18:0) were found minor amounts in these esters.

When biodiesel productivities of eight different oils were compared, similar results were obtained because of the fact that they have similar fatty acid content.

\section{Acknowledgements}

We would like to thank Ender Uzer, Seval Güner and other laboratory assistants from Trakya Olin Oil Factory (Edirne, Turkey), for provided vegetable unrefined oils and $\mathrm{GC}$ analysis supports.

\section{REFERENCES}

[1] Y. Zhang, M. A. Dube, D. D. Mc Lean and M. Kates, "Biodiesel Production from Waste Cooking Oil: 2. Economic Assessment and Sensitivity Analysis," Bioresource Technology, Vol. 90, No. 3, 2003, pp. 229-240. doi:10.1016/S0960-8524(03)00150-0

[2] H. Fukuda, A. Kondo and H. Noda, "Biodiesel Fuel Production by Transesterification of Oils," Journal of Bioscience and Bioengineering, Vol. 92, No. 5, 2001, pp. 405-416.

[3] F. R. Ma and M. A. Hanna, "Biodiesel Production: A Review," Bioresource Technology, Vol. 70, No. 1, 1999, pp. 1-15. doi:10.1016/S0960-8524(99)00025-5

[4] J. W. Goodrum and D. P. Geller, "Influence of Fatty Acid Methyl Esters from Hydroxylated Vegetable Oils on Diesel Fuel Lubricity," Bioresource Technology, Vol. 96, No. 7, 2005, pp. 851-855. doi:10.1016/j.biortech.2004.07.006

[5] T. F. Dossin, M. F. Reynier, R. J. Berger and G. B. Marin, "Simulation of Heterogeneously MgO-Catalyzed Transesterification for Fine-Chemical and Biodiesel İndustrial
Production," Applied Catalysis B: Environmental, Vol. 67, No. 1, 2006, pp. 136-148.

doi:10.1016/j.apcatb.2006.04.008

[6] X. Lang, A. K. Dalai, N. N. Bakhshi, M. J. Reaney and P. B. Hertz, "Preparation and Characterization of Bio-Die- sels from Various Bio-Oils," Bioresource Technology, Vol. 80, No. 1, 2001, pp. 53-62.

doi:10.1016/S0960-8524(01)00051-7

[7] A. Sagiroglu and A. Telefoncu, "Synthesis of Stereo Specific Esters and Resolution of Racemic Alcohols with İmmobilized Lipases," Preparative Biochemistry \& Biotechnology, Vol. 34, No. 2, 2004, pp. 169-178. doi:10.1081/PB-120030875

[8] S. Shah, S. Sharma and M. N. Gupta, "Biodiesel Preparation by Lipase-Catalyzed Transesterification of Jatropha Oil," Energy Fuels, Vol. 18, No. 1, 2004, pp. 154-159. doi:10.1021/ef030075z

[9] Y. Watanabe, Y. Shimada, A. Sugihara, H. Noda, H. Fukuda and Y. Tominaga, "Continuous Production of Biodiesel Fuel from Vegetable Oil Using İmmobilized Candida antartica Lipase," Journal of the American Oil Chemists' Society, Vol. 77, No. 4, 2000, pp. 355-360.

[10] V. Caballero, F. M. Batutista, J. M. Campelo, D. Luna, J. M. Marinas, A. A. Romero, J. M. Hidalgo, R. Luque, A. Macario and G. Giordano, "Susteinable Preparation of a Novel Glycerol-Free Biofuel by Using Pancreatic Lipase: Partial 1-3 Regiciospecific Alcoholysis of Sunflower Oil," Process Biochemistry, Vol. 44, No. 3, 2009, pp. 334-342. doi:10.1016/j.procbio.2008.11.015

[11] M. Oda, M. Kaieda, S. Hama, H. Yamaji, A. Kondo, E. Izumoto and H. Fukuda, "Facilitatory Effect of İmmobilized Lipase-Producing Rhizopus oryzae Cells on Acyl Migration in Biodiesel-Fuel Production," Biochemical Engineering Journal, Vol. 23, No. 1, 2005, pp. 45-51. doi:10.1016/j.bej.2004.10.009

[12] W. Du, Y. Y. Xu, D. H. Liu and Z. B. Li, "Study on Acyl Migration in İmmobilized Lipozyme TL-Catalyzed Transesterification of Soybean Oil for Biodiesel Production," Journal of Molecular Catalysis B: Enzymatic, Vol. 37, No. 1-6, 2005, pp. 68-71. doi:10.1016/j.molcatb.2005.09.008

[13] F. Camacho, A. Robles, P. González-Tello, B. CamachoPaez, L. Esteban and E. Molina, "Mechanistic Model for the Lipase-Catalyzed Alcoholysis of Triacylglycerols," Applied Catalysis A: General, Vol. 301, No. 2, 2006, pp. 158-168. doi:10.1016/j.apcata.2005.11.021

[14] G. Vicente, M. Martinez and J. Aracil, "Optimisation of İntegrated Biodiesel Production. Part I. A Study of the Biodiesel Purity and Yield," Bioresource Technolgy, Vol. 98, No. 9, 2007, pp. 1724-1733. doi:10.1016/j.biortech.2006.07.024

[15] M. Cetinkaya and F. Karaosmanoglu, "Optimization of Base Catalyzed Transesterification Reaction of Used Cooking Oil," Energy \& Fuels, Vol. 18, No. 6, 2004, pp. 1888-1895. doi:10.1021/ef049891c

[16] K. H. Chung, J. Kim and K. Young Lee, "Biodiesel Production by Transesterification of Duck Tallow with Methanol on Alkali Catalysts," Biomass \& Bioenergy, Vol. 33, No. 1, 2009, pp. 155-158. 
doi:10.1016/j.biombioe.2008.04.014

[17] X. Meng, G. Chen and Y. Wang, "Biodiesel Production from Waste Cooking Oil via Alkali Catalyst and İts
Engine Test," Fuel Processing Technology, Vol. 89, No. 9, 2008, pp. 851-857. 